\title{
The Unique Composition of Fatty Acids of Flax, from the Linum usitatissimum $\mathrm{L}$. collection
}

\author{
Grażyna SILSKA* \\ Institute of Natural Fibres \& Medicinal Plants, Polska \\ *Corresponding author: Grażyna SILSKA, Institute of Natural Fibres \& Medicinal Plants, Wojska Polskiego 71B, 60-630 Poznań, \\ Polska
}

\section{ARTICLE INFO}

Received: 幽 May 25, 2019

Published: 幽 June 04, 2019

Citation: Grażyna SILSKA. The Unique Composition of Fatty Acids of Flax, from the Linum usitatissimum L. collection. Biomed J Sci \& Tech Res 18(4)-2019. BJSTR. MS.ID.003178.

Keywords: Flax; Linum usitatissimum L; Valorisation; Genetic Resources; Technological Features; Fatty Acid Composition

\begin{abstract}
In Poland in the 1980 's of the $20^{\text {th }}$ century, the area of flax (Linum usitatissimum L.) grown was over 100,000 hectares. Flax seeds were used to prepare meals and for medicinal purposes, especially in the case of problems with the digestive tract. Unfortunately, currently farmers in Poland have stopped cultivating less profitable crop species, guided only by achieving the highest possible profit per hectare. The common flax (Linum usitatissimum L.) is characterized by the unique composition of fatty acids in seed oil, which is significantly different from most oils. The composition of fatty acids in flax oil is dominated by $\alpha$-linolenic fatty acid. The research material in the study consisted of 14 oil flax accessions from the Linum collection. The content of $\alpha$-linolenic fatty acid in the seed oil of studied accessions was higher at a minimum of 2.7 times (K-5327) and a maximum of 4.2 times (Canadian green seed) than the content of linoleic fatty acid. According to WHO standards, the amount of linoleic acid in the human diet may be higher than the amount of $\alpha$-linolenic acid by most 5 times. Therefore, the abandonment of common flax in Poland has serious health consequences resulting from insufficient amounts in the daily $\alpha$-linolenic fatty acid diet. All tested varieties of flax (Linum usitatissimum L.) had a high content of $\alpha$-linolenic fatty acid and very low linoleic fatty acid. The largest number of accessions had an average content of oleic and stearic fatty acid and low content of palmitic fatty acid. Fat content in seeds of 14 examined accessions from the collection of genetic resources of flax ranged from $36.3 \%$ (Zaretsky Kriaj) to $42.6 \%$ (Verne).
\end{abstract}

\section{Introduction}

Information on the genotypes of flax collected in Poland is therefore particularly important, because the composition of seeds of this species is extremely beneficial for human and animal health. An exceptionally deficient dietary ingredient in the human diet is the tri-unsaturated fatty acid $\alpha$-linolenic of the omega- 3 family. Insufficient amount of this very important, exogenous food ingredient contributes to the increase in so-called civilization diseases in Western countries. The most abundant natural source of $\alpha$-linolenic fatty acids are the gene resources of flax (Linum usitatissimum L.). In addition to the $\alpha$-linolenic fatty acid seeds are very rich in phenolic acids, dietary fiber, essential amino acids, some vitamins and microelements $[1,2]$. The aim of the publication was to present the seeds of flax (Linum usitatissimum L.) as a natural food ingredient with particularly high nutritional values due to the highest content of $\alpha$-linolenic acid among all food sources.
This unique and extremely beneficial chemical composition of flax seeds is characteristic of flax plants stored in the National Centre for Plant Genetic Resources of the Plant Breeding and Acclimatization Institute, such as old deregistered varieties, advanced lines, or accessions collected from the natural state during field expeditions. In contrast, some of the varieties currently registered have a changed fatty acid composition by breeders, which is characterized by a very small amount of $\alpha$-linolenic acid in seed oil, although this fatty acid is essential for maintaining health $[3,4]$. The protection and characterization of flax genetic resources is of particular importance for the protection of public health.

\section{Material and Methods}

Institute of Natural Fibres and Medicinal Plants is one of the subcontractors of the long-term program, whose aim is to collect 
and evaluate the genetic resources of useful plants. The coordinator of gene flax conservation is the Plant Breeding and Acclimatization Institute in Radzików, near Warsaw. This program is related to the Convention of Biodiversity signed by Poland and is financed by the Ministry of Agriculture and Rural Development [Convention of Biodiversity 1992] [5]. The genetic resources of flax were collected by the Institute of Natural Fibers and Medicinal Plants in Poznań, formerly the Institute of Natural Fibers, whose traditions date back to 1930. Genetic resources of flax are stored in the gene bank in the Institute for Plant Breeding and Acclimatization Institute are particularly important because they are the natural source of a deficient, exogenous nutrient of $\alpha$-linolenic acid.

Table I: Fatty acids - content of alfa-linolenic acid [\%].

\begin{tabular}{|c|c|c|}
\hline \multicolumn{2}{|c|}{ Descriptor states } & Ranges \\
\hline 1 & very low & $<11.1$ \\
\hline 3 & low & $11.1-24.5$ \\
\hline 5 & medium & $24.6-44.6$ \\
\hline 7 & high & $44.7-58.0$ \\
\hline 9 & very high & $>58.0$ \\
\hline
\end{tabular}

Table II: Fatty acids - content of linoleic acid [\%].

\begin{tabular}{|c|c|c|}
\hline \multicolumn{2}{|c|}{ Descriptor states } & Ranges \\
\hline 1 & very low & $<20.7$ \\
\hline 3 & low & $20.7-33.5$ \\
\hline 5 & medium & $33.6-52.6$ \\
\hline 7 & high & $52.7-65.4$ \\
\hline 9 & very high & $>65.4$ \\
\hline
\end{tabular}

Evaluation of genetic resources of flax consists in carrying out the morphological characteristics of the evaluated accessions, biological features, agricultural and qualitative features. Quality assessment consists in determining the composition of fatty acids, the most important of which is characteristic for naturally occurring in nature $\alpha$-linolenic fatty acid. The following fatty acids are also evaluated: linoleic, palmitic, stearic and oleic. The results of the content of individual fatty acids of accessions of flax were presented in this article using 5 descriptors (for characterization and evaluation of flax) for 5 fatty acids: $\alpha$-linolenic, linoleic, palmitic, stearic and oleic. The descriptor state of each of the 5 fatty acids can be: very low, low, medium, high, very high according Nôžková descriptors to the creation of the International Flax Data Base (IFDB) (Tables I-V) [6,7]. In 2017 an experiment was conducted on 14 accessions of flax sown in the field in Pętkowo, in the Wielkopolskie region (near Poznań) on small plots 1,6 $\mathrm{m}^{2}$. Assays determining the content of fat and the composition of fatty acids in linseed oil were performed at the IHAR-PIB Biochemical Laboratory in Poznań. The fat content was determined by infrared analysis (calibration performed on the basis of a seed sample at IHAR-PIB in Poznań) by means of a NIRS 6500 spectrophotometer with a reflection detector within the range of 400-2500 $\mathrm{nm}$. The composition of fatty acids by Byczyńska and Krzymański [8], based on gas chromatography of methyl esters of fatty acids contained in linseed oil [9]

Table III: Fatty acids - content of palmitic acid [\%].

\begin{tabular}{|c|c|c|}
\hline \multicolumn{2}{|c|}{ Descriptor states } & Ranges \\
\hline 1 & very low & $<3.9$ \\
\hline 3 & low & $3.9-5.2$ \\
\hline 5 & medium & $5.3-7.2$ \\
\hline 7 & high & $7.3-8.5$ \\
\hline 9 & very high & $>8.5$ \\
\hline
\end{tabular}

Table IV: Fatty acids - content of stearic acid [\%].

\begin{tabular}{|c|c|c|}
\hline \multicolumn{2}{|c|}{ Descriptor states } & Ranges \\
\hline 1 & very low & $<1.5$ \\
\hline 3 & low & $1.5-2.6$ \\
\hline 5 & medium & $2.7-4.2$ \\
\hline 7 & high & $4.3-5.2$ \\
\hline 9 & very high & $>5.2$ \\
\hline
\end{tabular}

Table V: Fatty acids - content of oleic acid [\%].

\begin{tabular}{|c|c|c|}
\hline \multicolumn{2}{|c|}{ Descriptor states } & Ranges \\
\hline 1 & very low & $<14.1$ \\
\hline 3 & low & $14.1-19.0$ \\
\hline 5 & medium & $19.1-26.4$ \\
\hline 7 & high & $26.5-31.3$ \\
\hline 9 & very high & $>31.3$ \\
\hline
\end{tabular}

\section{Results}

The content of fat and the composition of fatty acids in 14 linseed accessions of flax are shown in Table 1 and according descriptors to the creation of the International Flax Data Base in Table 2. The results of the researches of fat content and fatty acid composition according to International Flax Data Base development descriptors along with variability ranges in particular groups (very low, low, medium, high) are presented below:

a) C16:0, palmitic acid: low $(4.0 \%-5.2 \%)-8$ accessions, medium $(5.4 \%-5.9 \%)-6$ accessions;

b) C18:0, stearic acid; low $(2.2 \%-2.5 \%)-3$ accessions, medium $(2.8 \%-3.8 \%)-10$ accessions, high (4.5\%) - 1 accession

c) C18:1, oleic acid; medium $(19.4 \%-25.2 \%)-13$ accessions, high (30.0\%) - 1 accession

d) C18:2, linoleic acid; very low (13.3\% - 18.9\%) - 14 accessions

e) C18:3, $\alpha$-linolenic acid: high $(48.1 \%-55.7 \%)-14$ accessions. 
Table 1: Characterization of the content of fat and fatty acids composition of linseed varieties of flax (Linum usitatissimum L.).

\begin{tabular}{|c|c|c|c|c|c|c|c|c|}
\hline \multirow{3}{*}{ Accename } & \multirow{3}{*}{ Coolnumb } & \multirow{3}{*}{ Fat } & \multicolumn{2}{|c|}{ Saturated fatty acids } & \multirow{2}{*}{$\begin{array}{c}\text { Monounsaturated } \\
\text { C 18:1 } \\
\text { n-9 } \\
\text { oleic }\end{array}$} & \multicolumn{2}{|c|}{ Polyunsaturated } & \multirow{3}{*}{$n-6: n-3$} \\
\hline & & & $\begin{array}{c}\text { C 16:0 } \\
\text { palmitic }\end{array}$ & $\begin{array}{l}\text { C 18:0 } \\
\text { stearic }\end{array}$ & & $\begin{array}{c}\text { C 18:2 } \\
n-6 \\
\text { linoleic }\end{array}$ & $\begin{array}{c}\text { C 18:3 } \\
\text { n-3 } \\
\alpha \text {-linolenic }\end{array}$ & \\
\hline & & & [\%] & [\%] & [\%] & [\%] & [\%] & \\
\hline $\begin{array}{c}\text { Elise } \\
\text { INF00641 }\end{array}$ & 166141 & 38.8 & 4.9 & 3.1 & 19.7 & 18.9 & 53.1 & $1: 2.8$ \\
\hline $\begin{array}{c}\text { Escalina } \\
\text { INF00642 }\end{array}$ & 166142 & 38.8 & 5.4 & 4.5 & 19.4 & 16.7 & 53.6 & $1: 3.2$ \\
\hline $\begin{array}{c}\text { Liflora } \\
\text { INF00643 }\end{array}$ & 166150 & 41.2 & 4.6 & 3.2 & 30 & 13.7 & 48.1 & $1: 3.5$ \\
\hline $\begin{array}{c}\text { Verne } \\
\text { INF00644 }\end{array}$ & 166143 & 42.6 & 5.4 & 2.8 & 23.8 & 15.8 & 51.7 & $1: 3.3$ \\
\hline $\begin{array}{l}\text { Slavny } 82 \\
\text { INF00645 }\end{array}$ & 166144 & 39.9 & 5.4 & 2.8 & 21.8 & 15 & 54.5 & $1: 3.6$ \\
\hline $\begin{array}{c}\text { Clark } \\
\text { INF00646 }\end{array}$ & 166151 & 41.3 & 5.9 & 3.2 & 25.2 & 14.5 & 50.9 & $1: 3.5$ \\
\hline $\begin{array}{c}\text { K-5327 } \\
\text { INF00649 }\end{array}$ & 166145 & 38.9 & 5.2 & 2.8 & 23.9 & 18.1 & 49.3 & $1: 2.7$ \\
\hline $\begin{array}{l}\text { Canadian green seed } \\
\text { INF00670 }\end{array}$ & 165722 & 39.8 & 5.5 & 2.8 & 22.7 & 13.3 & 55.7 & $1: 4.2$ \\
\hline $\begin{array}{c}\text { Germes } \\
\text { INF00708 }\end{array}$ & 165863 & 42.1 & 5.1 & 3.2 & 20.7 & 16.8 & 53.9 & $1: 3.2$ \\
\hline $\begin{array}{c}\text { KLN-1 } \\
\text { INF00710 }\end{array}$ & 165983 & 40.9 & 5.2 & 2.5 & 20.6 & 18.4 & 53.3 & $1: 2.9$ \\
\hline $\begin{array}{c}\text { Mestny } \\
\text { INF00711 }\end{array}$ & 166111 & 38.2 & 4 & 2.4 & 20.9 & 17.1 & 55 & $1: 3.2$ \\
\hline $\begin{array}{c}\text { Novotorzhsky } \\
\text { INF00713 }\end{array}$ & 166276 & 40.3 & 5.1 & 3.8 & 23.4 & 16.2 & 51.1 & $1: 3.2$ \\
\hline $\begin{array}{c}\text { Zaretsky Kriaj } \\
\text { INF00721 }\end{array}$ & & 36.3 & 5.2 & 2.2 & 22.9 & 15.5 & 53.8 & $1: 3.5$ \\
\hline $\begin{array}{c}\text { Alaska } \\
\text { INF00881 }\end{array}$ & 165584 & 40.6 & 5.9 & 3.5 & 23.3 & 14.4 & 52.5 & $1: 3.6$ \\
\hline Min & & 36.3 & 4 & 2.2 & 19.4 & 13.3 & 48.1 & $1: 2.7$ \\
\hline Max & & 42.6 & 5.9 & 4.5 & 30 & 18.9 & 55.7 & $1: 4.2$ \\
\hline
\end{tabular}

Table 2: Characterization of the content of fatty acids in seeds from the collection of genetic resources of flax (Linum usitatissimum L.) according Nôžková descriptors.

\begin{tabular}{|c|c|c|c|c|c|c|}
\hline \multirow{3}{*}{ Accename } & \multirow{3}{*}{ Coolnumb } & \multicolumn{2}{|c|}{ Saturated fatty acids } & \multirow{2}{*}{$\begin{array}{c}\text { Monounsaturated } \\
\text { C 18:1 } \\
\text { n-9 } \\
\text { oleic } \\
\end{array}$} & \multicolumn{2}{|c|}{ Polyunsaturated } \\
\hline & & $\begin{array}{l}\text { C 16:0 } \\
\text { palmitic }\end{array}$ & $\begin{array}{l}\text { C 18:0 } \\
\text { stearic }\end{array}$ & & $\begin{array}{c}\text { C 18:2 } \\
n-6 \\
\text { linoleic }\end{array}$ & $\begin{array}{c}\text { C 18:3 } \\
\text { n-3 } \\
\alpha \text {-linolenic } \\
\end{array}$ \\
\hline & & [\%] & [\%] & {$[\%]$} & [\%] & [\%] \\
\hline $\begin{array}{c}\text { Elise } \\
\text { INF00641 }\end{array}$ & 166141 & low & medium & medium & very low & high \\
\hline $\begin{array}{l}\text { Escalina } \\
\text { INF00642 }\end{array}$ & 166142 & medium & high & medium & very low & high \\
\hline $\begin{array}{c}\text { Liflora } \\
\text { INF00643 }\end{array}$ & 166150 & low & medium & high & very low & high \\
\hline $\begin{array}{c}\text { Verne } \\
\text { INF00644 }\end{array}$ & 166143 & medium & medium & medium & very low & high \\
\hline
\end{tabular}




\begin{tabular}{|c|c|c|c|c|c|c|}
\hline $\begin{array}{c}\text { Slavny } 82 \\
\text { INF00645 }\end{array}$ & 166144 & medium & medium & medium & very low & high \\
\hline $\begin{array}{c}\text { Clark } \\
\text { INF00646 }\end{array}$ & 166151 & medium & medium & medium & very low & high \\
\hline $\begin{array}{c}\text { K-5327 } \\
\text { INF00649 }\end{array}$ & 166145 & low & medium & medium & very low & high \\
\hline $\begin{array}{l}\text { Canadian green } \\
\text { seed } \\
\text { INF00670 }\end{array}$ & 165722 & medium & medium & medium & very low & high \\
\hline $\begin{array}{c}\text { Germes } \\
\text { INF00708 }\end{array}$ & 165863 & low & medium & medium & very low & high \\
\hline $\begin{array}{c}\text { KLN-1 } \\
\text { INF00710 }\end{array}$ & 165983 & low & low & medium & very low & high \\
\hline $\begin{array}{c}\text { Mestny } \\
\text { INF00711 }\end{array}$ & 166111 & low & low & medium & very low & high \\
\hline $\begin{array}{l}\text { Novotorzhsky } \\
\text { INF00713 }\end{array}$ & 166276 & low & medium & medium & very low & high \\
\hline $\begin{array}{l}\text { Zaretsky Kriaj } \\
\text { INF00721 }\end{array}$ & & low & low & medium & very low & high \\
\hline $\begin{array}{c}\text { Alaska } \\
\text { INF00881 }\end{array}$ & 165584 & medim & medium & medium & very low & high \\
\hline \multirow{5}{*}{$\begin{array}{l}\text { State of descriptors } \\
\text { according } \\
\text { Nôžková J. } 2011\end{array}$} & very low & ----- & ----- & ---- & 14 & ---- \\
\hline & low & 8 & 3 & ---- & ----- & ---- \\
\hline & medium & 6 & 10 & 13 & ----- & ---- \\
\hline & high & ---- & 1 & 1 & ---- & 14 \\
\hline & very high & ---- & ---- & $-\cdots--$ & ---- & $-\cdots-$ \\
\hline
\end{tabular}

\section{Discussion}

Providing the organism with essential omega -3 fatty acids in the daily diet is extremely important due to the fact that people cannot synthesize double carbon bonds in n-3 (omega-3) and n-6 (omega-6) position [10]. The second reason why the provision of tri-unsaturated fatty acid $\alpha$-linolenic in the diet is very important is that most food sources predominate linoleic fatty acid from a few to few hundred times (Table 3). Another argument for consumption of omega- 3 is the fact that in the diet of Western countries 10 to 30 times more omega- 6 (linoleic fatty acid) is consumed than omega- 3 fatty acids, with causes severe health consequences, inflammations and lifestyle diseases [11]. The results of epidemiological and clinical studies indicate that lifestyle, defined as the combination of nutrition and physical activity, affects health condition of people [9].

Table 3: Characterization of different oil according fatty acids and n-6 fatty acids/ n-3 fatty acids.

\begin{tabular}{|c|c|c|c|c|c|c|c|c|}
\hline Type of fat & Linseed oil & $\begin{array}{c}\text { Fish oil } \\
\text { (herring) }\end{array}$ & Rapeseed oil & Soy oil & Olive oil & Corn oil & $\begin{array}{c}\text { Grape seed } \\
\text { oil }\end{array}$ & Sunflower oil \\
\hline C $16: 0$ & 5.06 & 13.9 & 4.68 & 10.62 & 11.46 & 10.1 & 6.79 & 6.66 \\
\hline C $18: 0$ & 3.73 & 2.7 & 2.36 & 3.76 & 2.2 & 1.6 & 3.63 & 4.27 \\
\hline C $18: 1 \mathrm{n}-9$ & 19.68 & 11.6 & 57.14 & 21.67 & 68.76 & 31.4 & 17.8 & 24.2 \\
\hline C $18: 2 \mathrm{n}-6$ & 16.21 & 12.4 & 21.16 & 55.07 & 10.51 & 47 & 65.9 & 63.65 \\
\hline C $18: 3 \mathrm{n}-3$ & 54.52 & 2.1 & 11.25 & 6.89 & 0.67 & 0.4 & 0.38 & 0.19 \\
\hline $\mathrm{n}-6: \mathrm{n}-3$ & $0.30: 1$ & $0.44: 1$ & $2: 1$ & $8: 1$ & $16: 1$ & $141: 1$ & $173: 1$ & $335: 1$ \\
\hline
\end{tabular}

Increase in numbers of the so-called lifestyle diseases is also significant in Poland, therefore it is essential to inform the society on the huge effect on our health of environmental factors, including valuable high-quality food products [12]. The ranges of variability of fat content and fatty acid composition by different authors are presented in Table 4. Considering the studies of several authors regarding the Linum usitatissimum species (Table 4), the research material 14 flax genotypes contained objects that were characterized by the smallest or the largest amount of fatty acids in seed oil (Table 4). Among the 14 valorized flax accessions Liflora contained the smallest amount of $\alpha$-linolenic acid (48.1\%), Mestny the lowest amount of palmitic acid (4\%), Zaretsky Kriaj the smallest amount of stearic acid (2.2\%) contained in the oil from flax seeds, examined by several authors (Table 4). 
Table 4: Fat content and fatty acids composition of flax (Linum usitatissimum L.) according to several authors.

\begin{tabular}{|c|c|c|c|c|c|c|c|}
\hline \multirow{2}{*}{$\begin{array}{l}\text { According to } \\
\text { the authors }\end{array}$} & \multirow{2}{*}{ Fat content [\%] } & \multirow{2}{*}{$\begin{array}{c}\text { Fatty acid } \\
\alpha \text {-linolenic } \\
\text { Ala } \\
{[\%]}\end{array}$} & \multirow{2}{*}{$\begin{array}{c}\text { Fatty acid } \\
\text { Linoleic } \\
\text { La } \\
\text { [\%] }\end{array}$} & \multirow{2}{*}{$\begin{array}{c}\text { Fatty acid } \\
\text { Oleic }\end{array}$} & \multicolumn{2}{|c|}{ Saturated } & \multirow{2}{*}{$\begin{array}{l}n-6: n-3 \\
\text { (The ratio of the } n-6 \text { familly } \\
\text { to the } n-3 \text { familly) }\end{array}$} \\
\hline & & & & & Palmitic & Stearic & \\
\hline Zając 2002 & $39.4-44.8$ & 49.6-56.9 & $11.9-17.8$ & $19-26$ & $6.1-7.1$ & 3-5.1 & $1: 3-1: 4.5$ \\
\hline $\begin{array}{l}\text { Mińkowski i inni } \\
2011\end{array}$ & & 52.7 & 16.2 & 21.2 & \multicolumn{2}{|c|}{---} & $1: 3.3$ \\
\hline $\begin{array}{c}\text { Silska, Praczyk } \\
2012\end{array}$ & $37.4-42.7$ & $50.9-59.2$ & $9.6-14.5$ & $19.2-26.4$ & $4-5.8$ & $2.7-6.1$ & $1: 3.7-1: 5.8$ \\
\hline $\begin{array}{l}\text { Ludvikova, Griga } \\
2015\end{array}$ & $35-45$ & $52-60$ & $13-18$ & $16-20$ & about 6 & about 3 & \\
\hline Silska 2017 & $42.7-52$ & 48.9-59.9 & $12.4-17.1$ & $17.1-26.7$ & $4.7-6$ & $2.3-5$ & $1: 3.1-1: 4.4$ \\
\hline this research & $36.3-42.6$ & $48.1-55.7$ & $13.3-18.9$ & 19.4-30 & $4-5.9$ & $2.2-4.5$ & $1: 2.7-1: 4.2$ \\
\hline Min & 35 & 48.1 & 9.6 & 16 & 4 & 2.2 & $1: 2.7$ \\
\hline Max & 45 & 60 & 18.9 & 30 & 7.05 & 6.1 & $1: 5.8$ \\
\hline
\end{tabular}

In turn, the largest amount of fatty acids: oleic acid contained Liflora (30\%) and Elise linoleic acid (18.9\%), taking into account the variability range of these acids in the study of several authors (Table 4). A diet which includes non-hydrogenated unsaturated fats as the predominant form of dietary fat, whole grains as the main form of carbohydrates, an abundance of fruits and vegetables and adequate omega-3 fatty acids, can offer significant protection against CHD." [13]. The results of testing the fat content and fatty acid composition in the seeds of other accessions from the flax gene collection can be found in the publications from 2012 and 2017 [14-18].

\section{Conclusion}

The composition of fatty acids in flax seeds from the collection of genetic resources is unique, because $\alpha$-linolenic acid predominates in them, while in most other oilseed species, linoleic or oleic fatty acid prevails.

In the evaluated 14 accessions of flax (Linum usitatissimum L.) the content of $\alpha$-linolenic acid was greater than the content of linoleic acid from 2.7 times (K-5327) to 4.2 times (Canadian green seed). For health reasons, farmers should grow flax to provide their family with seeds, the consumption of which protects against many serious diseases of civilization. The content of $\alpha$-linolenic acid in evaluated genotypes of flax ranged from $48.1 \%$ (Liflora) to $55.7 \%$ (Canadian green seed). The content of linoleic acid in evaluated accessions of flax ranged from $13.3 \%$ (Canadian green seed) to $18.9 \%$ (Elise). The content of oleic acid of 14 genotypes of flax ranged from $19.4 \%$ (Escalina) to $30 \%$ (Liflora).

The content of stearic acid in evaluated genotypes of flax ranged from 2.2\% (Zaretsky Kriaj) to $4.5 \%$ (Escalina) and the content of palmitic acid ranged from $4 \%$ (Mestny) to $5.9 \%$ (Clark). The content of fat ranged from $36.3 \%$ (Zaretsky Kriaj) to $42.6 \%$ (Verne). The ratio of $n-6$ family to $n-3$ family of fatty acids ranged from 1:2.72 (K-5327) to 1:4.19 (Canadian green seed)

\section{Acknowledgment}

This research was financially supported by the Ministry of Agriculture and Rural Developmentof the Departament of Plant Breeding and Protection (long-term program "Creating the scientific basis of biological progress and protecting plant genetic resources as a source of innovation and support for sustainable agriculture and food security of the country", excluding tasks 1.3 and 1.7, contract No. HORzg 8424/1/2018), Institute of Natural Fibres and Medicinal Plant.

\section{References}

1. Mińkowski K, Grześkiewicz S, Jerzewska M (2011) Assessment of nutritive value of plant oils with high content of linolenic acids based on the composition of fatty acids, tocopherols and sterols. ZNTJ 2(75): 124-135.

2. Obiedzińska A, Waszkiewicz Robak B (2012) Cold pressed oils as functional food. ZNTJ 1(80): 27-44.

3. Ludvikowa M, Griga M (2015) Transgenic flax/Linseed (Linum usitatissimum L.), Czech J. Genet Plant Breed 51(4): 123-141.

4. Walkowiak M, Silska G, Michalski K, Praczyk M (2016) Characterization of a collection of linseed (Linum usitatissimum L.) with varying fat content and composition of fatty acids in seed oil. In Proceeding of the 31 Polish Conference: Advances in genetics, breeding, technology and analytics of lipids; Poznań 2016: 71-72.

5. Convention on Biological Diversity (1992).

6. Nôžková J (2011) Descriptor list for flax (Linum usitatissimum L.) (1 $1^{\text {st }}$ Edn.). Nitra. Slovak University of Agriculture 1-101.

7. Silska G, Praczyk M (2013) Descriptors of characterization and evaluation of International Flax Database. Biul. Inst Hod Rośl 268: 161171.

8. Byczyńska B, Krzymański J (1969) Szybki sposób otrzymywania estrów metylowych kwasów tłuszczowych do analizy metodą chromatografii fazowej. Tłuszcze Jadalne 13: 108-114.

9. Trziszka T (2015) Nutraceuticals and their importance in human nutrition; III Congress of Agricultural Sciences Research in the process of shaping the Polish vision of the Common Agricultural policy and the Common Fisheries Policy, 261.

10. Gawęcki J (1997) The chemical nature of fat and its nutritional value In: Gawęcki (Edn) The truth about fats. $1^{\text {st }}(E d n)$ Institute of Danone Foundation for the Promotion of Healthy Nutrition P.10-12. 
11. Matławska I, Bylka W (2007) Naturalne niezbędne kwasy tłuszczowe w profilaktyce chorób cywilizacyjnych. Herba Pol 53(2): 39-40.

12. Silska G (2017) Promotion of flax rich in bioactive compounds that protect health-conference materials P. 79.

13. Kolarzyk E, Skop Lewandowska A, Jaworska J, Ostachowska Gąsior A Krzeszowska Rosiek T (2018) Dietary intake of antioxidants and fats in the context of coronary heart disease prevention among elderly people; Annals of Agricultural and Environmental Medicine 25(1): 131-136.

14. Silska G, Praczyk M (2012) Ocena obiektów lnu oleistego (Linum usitatissimum L.) Rośliny Oleiste, 33(1): 127-138.

\section{ISSN: 2574-1241}

DOI: 10.26717/BJSTR.2019.18.003178

Grażyna SILSKA. Biomed J Sci \& Tech Res

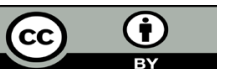

This work is licensed under Creative Commons Attribution 4.0 License

Submission Link: https://biomedres.us/submit-manuscript.php
15. Silska G (2016) Polska kolekcja lnu źródłem nasion o terapeutycznym działaniu. Zagadnienia Doradztwa Rolniczego 4: 73-81.

16. Silska G (2017) Genetic resources of flax (Linum usitatissimum L.) as very rich source of $\alpha$-linolenic acid. Herba Pol 63(4): 26-33.

17. Silska G (2017) Gatunek len zwyczajny w prewencji chorób nowotworowych-materiały konferencyjne Medycyna naturalna w onkologii str. 13.

18. Walkowiak M, Krótka K, Wielebski F, Michalski K, Silska G, et al. (2018) Analysis of variability and correlation of functional traits of linseed (Linum usitatissimum L.) cultivars and breeding lines. Fragmenta Agronomika 35(4): 123-137.

$\begin{array}{ll}\text { BIOMEDICAL } & \text { Assets of Publishing with us } \\ \text { RESEARCHES } & \text { - Global archiving of articles } \\ & \text { - Immediate, unrestricted online access } \\ & \text { - Rigorous Peer Review Process } \\ \end{array}$

